\title{
ANALISIS PPM DENGAN ORIENTASI KEGIATAN PBL
}

\author{
Dini (70200120015) \\ Kesehatan Masyarakat
}

Fakultas Kedokteran dan Ilmu Kesehatan

Universitas Islam Negeri Alauddin Makassar

Judul : Laporan Pengalaman Belajar Lapangan (PBL) II Dusun Tanete Labba

Desa Baji Pa'mai Kec. Cenrana Kab Maros Tahun 2020)

Posko : 2

Angkatan : 2018

\begin{abstract}
Abstrak
Dewasa ini, masih terdapat berbagai permasalahan kesehatan yang serius yang kita temui dalam masyarakat. Faktor kesehatan mulai dari lingkungan genetik, hingga pelayanan kesehatan nyatanya belum saling bersinergi secara baik dalam penyebarannya di masyarakat. Belum lagi kesenjangan sarana prasarana dan pelayanan kesehatan yang masih sering terjadi antara masyarakat di kota dan di desa.

Pemberdayaan masyarakat akan menitikberatkan kepada kemandirian masyarakat untuk mewujudkan kesehatan mereka agar lebih baik, dengan tentunya didukung peran petugas kesehatan sebagai fasilitator. Seluruh stakeholder diharapkan pro aktif dalam mendukung percepatan pembangunan kesehatan nasional yang berbasis preventif dan promotif.
\end{abstract}

\section{A. Pembahasan}

\section{Persiapan}

Salah satu Program Studi Kesehatan Masyarakat Islam Negeri (UIN) Alauddin Makassar, yang merupakan sebuah institusi kesehatan masyarakat, mempunyai komitmen moral dan kompetensi yang memadai dalam hal akademik dan pengembangan berbasis masyarakat (sosial community development) untuk mendukung 
pencapaian Indonesia sehat melalui pembelajaran di masyarakat berupa kegiatan Pengalaman Belajar Lapangan (PBL) II di masyarakat berupa kegiatan intervensi berupa evidence base dan asset base yang telah di kumpulkan pada saat PBL I.

\section{Perencanaan}

Dengan bermodalkan hasil pendataan yang dilakukan pada PBL I, dan mempertimbangkan situasi, kondisi, serta kestersediaan sumber daya manusia, sehingga mengangkat 3 permasalahan sebagai prioritas utama dalam intervensi yang dilakukan di Dusun Tanete Labba, Desa Baji Pa'mai, Kecamatan Cenrana, Kabupaten Maros. Ketiganya yaitu masalah perilaku pemeriksaan kesehatan, perilaku merokok dalam rumah dan pengolahan sampah. Prioritas inilah yang kemudian dijadikan rujukan intervensi fisik maupun non fisik yang dilakukan. Berdasarkan hasil tersebut, maka di rumuskan beberapa pelatihan kegiatan yaitu penyuluhan perilaku pemeriksaan kesehatan dan perilaku merokok dalam rumah, pelatihan pengolahan sampah, pembuatan papan wicara dan pembuatan toga percontohan. Diharapkan dengan pelaksanakan berbagai kegiatan ini, dapat menjadi sumbangsih nyata dalam melakukan pengabdian kepada masyarakat.

Adapun perencanaan kegiatan dibagi menjadi intervensi fisik dan nonfisik, diantaranya:

- Intervensi fisik

1) Pemanfaatan TOGA

2) Pelatihan Pengolahan Sampah dengan Konsep Ecobrick

3) Pembuatan Papan Wicara

- Intervensi non-fisik

1) Penyuluhan Pentingnya Pemeriksaan Kesehatan

2) Penyuluhan Bahaya Merokok di dalam Rumah 


\section{Pelaksanaan}

Dari berbagai permasalahan yang telah di identifikasi, kelompok PBL II mencoba menyusun tingkatan prioritas masalah yang menjadikan patokan dalam merancang intervensi kepada masyarakat. Prioritas masalah yang di buat menggunakan juga mengacu pada hasil Focus Group Discussion Bersama tokoh masyarakat Dusun Tanete Labba. Selanjutnya, menetapkan prioritas masalah dengan metoda matematik.

Dari prioritas masalah tersebut, terdapat beberapa program intervensi yang ditawarkan, yaitu:

1) Penanganan Sampah

Program intervensi untuk Penanganan sampah dilakukan dengan cara Pelatihan Pengolahan Sampah Dengan Konsep Ecobrick dan Pembuatan Papan Wicara di dua titik tempat pembuangan sampah yang dilakukan oleh warga Dusun Tanete Labba secara sembarangan.

2) Perilaku Merokok Dalam Rumah

Dalam mengatasi permasalahan perilaku merokok dalam rumah program intervensi yang di tawarkan adalah Penyuluhan Bahaya Merokok Dalam Rumah. Selain itu pemberian Leaflet dari rumah ke rumah warga dusun Tanete Labba tentang bahaya merokok di dalam rumah.

3) Cakupan Pemanfaatan TOGA

Program intervensi yang ditawarkan berupa pembuatan TOGA Percontohan agar memudahkan masyarakat Desa Baji Pa'mai untuk mendapatkan tanaman obat .

4) Perilaku Pemeriksaan Kesehatan Rutin

Program intervensi yang ditawarkan berupa Penyuluhan dan Pembuatan leafleat tentang pentingnya memeriksakan kesehatan secara rutin. Penentuan intervensi berdasarkan prioritas masalah dengan menggunakan metode Delbiq 
disampaikan pada kegiatan Focus Group Discussion (FGD) bersama dengan tokoh masyarakat dengan tujuan untuk mendapatkan persetujuan serta menyelaraskan prioritas masalah yang didapatkan dengan kondisi masyarakat di Tanete Labba, Desa Baji Pa'mai, Kecamatan Cenrana, Kabupaten Maros, yang dilaksanakan sebagai intervensi fisik maupun non-fisik dari masing-masing masalah.

\section{Factor Pendukung dan Penghambat Pelaksanaan}

Ada beberapa faktor pendukung yang mempengaruhi sehingga kegiatan PBL II ini dapat berjalan sesuai yang diharapkan, antara lain :

1) Berkat dukungan dan partisipasi dari pemerintah setempat khususnya Kepala Desa Baji Pa'mai, Kepala Dusun Tanete Labba, beserta aparat pemerintahan lainnya yang sangat membantu dalam suksesnya kegiatan intervensi pada saat PBL II.

2) Keterbukaan, sikap ramah, dan kerjasama dari tokoh masyarakat dan tokoh agama di Dusun Tanete Labba.

3) Adanya bimbingan, arahan, dan masukan dari pembimbing PBL II sehingga memudahkan dalam melakukan intervensi.

4) Semangat, kerjasama, dan kekompakan dari teman-teman peserta PBL Posko 2 dalam melakukan intervensi fisik dan non-fisik yang dilakukan.

5) Kerjasama rekan-rekan PBL posko lainnya yang telah memberikan sumbangsih pemikiran dan konsumsi serta 
melakukan program kolaborasi sehingga bisa bersemangat dalam melakukan intervensi di Dusun Tanete Labba.

Adapun beberapa faktor penghambat yang mempengaruhi, sehingga kegiatan PBL II ini tidak berjalan sesuai dengan yang diharapkan, antara lain:

1) Kesulitan dalam mengumpulkan warga di suatu tempat karena faktor pekerjaan yang sebagian besar berstatus petani dan pedagang sehingga mobilitas penduduk tingga dan waktu luang sangat terbatas.

2) Masih kurangnya tokoh masyarakat yang dapat menjadi motor penggerak untuk membangkitkan antusiasme masyarakat dalam mengikuti setiap kegiatan yang dilaksanakan.

3) Cuaca ekstrim, yaitu hujan deras disertai angin kencang.

4) Waktu untuk melakukan intervensi sangat singkat karena adanya penundaan seminar PBL 1 dan libur kegiatan Pemilihan Umum (pemilu).

\section{Evaluasi}

Perlunya kerja sama dalam berbagai hal antara masyarakat dengan bagian pemerintahan setempat, agar pemerintah dapat mengetahui secara langsung masalah yang terjadi di masyarakat. Diharapkan dengan adanya intervensi yang dilakukan masyarakat dapat lebih antusias dalam menjaga kebersihan lingkungan sekitar dan meningkatkan rasa kebersamaan dan gotong-royong masyarakat serta pengetahuan masyarakat lebih meningkat terkait dengan masalah kesehatan. 